\title{
ZnO Nanoparticles Protect RNA from Degradation Better than DNA
}

\author{
Jayden McCall ${ }^{1}$ (D), Joshua J. Smith ${ }^{2}$, Kelsey N. Marquardt ${ }^{2}$, Katelin R. Knight ${ }^{2}$, Hunter Bane ${ }^{2}$, \\ Alice Barber ${ }^{2}$ and Robert K. DeLong ${ }^{1, *}$ \\ 1 Nanotechnology Innovation Center Kansas State (NICKS), Department of Anatomy and Physiology, \\ College of Veterinary Medicine, Manhattan, KS 66506, USA; pcf17@ksu.edu \\ 2 Department of Biomedical Sciences, College of Health and Human Services, Missouri State University, \\ Springfield, MO 65897, USA; JoshuaJSmith@MissouriState.edu (J.J.S.); \\ Marquardt410@live.missouristate.edu (K.N.M.); Katelin126@live.missouristate.edu (K.R.K.); \\ Bane3@live.missouristate.edu (H.B.); AliceBarber@UTA.edu (A.B.) \\ * Correspondence: robertdelong@ksu.edu; Tel.: +1-785-532-6313
}

Received: 22 September 2017; Accepted: 31 October 2017; Published: 8 November 2017

\begin{abstract}
Gene therapy and RNA delivery require a nanoparticle (NP) to stabilize these nucleic acids when administered in vivo. The presence of degradative hydrolytic enzymes within these environments limits the nucleic acids' pharmacologic activity. This study compared the effects of nanoscale $\mathrm{ZnO}$ and $\mathrm{MgO}$ in the protection afforded to DNA and RNA from degradation by DNase, serum or tumor homogenate. For double-stranded plasmid DNA degradation by DNase, our results suggest that the presence of $\mathrm{MgO} \mathrm{NP}$ can protect DNA from DNase digestion at an elevated temperature $\left(65^{\circ} \mathrm{C}\right)$, a biochemical activity not present in $\mathrm{ZnO}$ NP-containing samples at any temperature. In this case, intact DNA was remarkably present for MgO NP after ethidium bromide staining and agarose gel electrophoresis where these same stained DNA bands were notably absent for ZnO NP. Anticancer RNA, polyinosinic-polycytidylic acid (poly I:C) is now considered an anti-metastatic RNA targeting agent and as such there is great interest in its delivery by NP. For it to function, the NP must protect it from degradation in serum and the tumor environment. Surprisingly, ZnO NP protected the RNA from degradation in either serum-containing media or melanoma tumor homogenate after gel electrophoretic analysis, whereas the band was much more diminished in the presence of $\mathrm{MgO}$. For both $\mathrm{MgO}$ and $\mathrm{ZnO} \mathrm{NP}$, buffer-dependent rescue from degradation occurred. These data suggest a fundamental difference in the ability of $\mathrm{MgO}$ and $\mathrm{ZnO}$ NP to stabilize nucleic acids with implications for DNA and RNA delivery and therapy.
\end{abstract}

Keywords: DNase; RNase; DNase activity; RNase activity; metal oxide nanoparticle (MONP); gel electrophoresis; $\mathrm{MgO}$; $\mathrm{ZnO}$; DNA stability; RNA stability

\section{Introduction}

In nanomedicine, the specific anticancer activity of zinc oxide $(\mathrm{ZnO})$ nanoparticle $(\mathrm{NP})$ is believed to be due to its reactive oxygen species (ROS) generation and tumor $\mathrm{pH}$-dependent ion disassociation as well as the inhibition of various kinases important in cancer cell signaling [1-4]. Poly inosinic:poly cytidilic acid (poly I:C) is among the most well-characterized anticancer RNA, possessing RNA targeting and anti-metastatic activity [5-7]. Our group has studied the interaction and delivery of poly I:C by ZnO NP [8,9]. Magnesium is best known to stabilize RNA structure-function; however, ironically, in the nanoscale $(<100 \mathrm{~nm})$, the effect of the corresponding antibacterial metal oxide, magnesium oxide (MgO) NP [10,11], on nucleic acids is unknown. RNA is particularly susceptible to hydrolysis catalyzed rapidly by nucleases (RNases) present in biological fluids (e.g., serum) and tissues (e.g., tumor). Similarly, DNA is susceptible to degradation by DNase enzymes. Previously, we have 
shown that complexation of plasmid DNA vaccine or siRNA (small interfering RNA) to certain types of organic NP or organic-inorganic hybrid NP is protective [12,13]; however, the influence of $\mathrm{ZnO}$ or $\mathrm{MgO}$ NP chemistries on DNA and RNA degradation is an important unanswered question and has never before been compared. Further, it was recently discovered that ZnO NP acts as a biochemical inhibitor of the bacterial enzyme, beta-galactosidase ( $\beta-\mathrm{Gal})$ which has been linked to its antibacterial activity [14]. The presence of such hydrolytic and degradative enzymes in serum or tumor environment may indicate cancer cell escape from the tumor compartment or otherwise contribute to metastasis or immuno-suppression. Thus, the impact that NP have on enzyme activity in these environments is important, and further their ability to inhibit biomolecular degradation will likely influence the extent and time-course of the DNA or RNA biological activity. Here, we show for the first time that when DNase is heat treated, the presence of $\mathrm{MgO}$ but not $\mathrm{ZnO}$ NP protects against DNA degradation. However, for RNA (poly I:C), the integrity of the full-length RNA as measured by gel electrophoresis is best protected in the presence of $\mathrm{ZnO} N \mathrm{~N}$ but not $\mathrm{MgO}$, after exposure to serum-containing media and mouse melanoma tumor homogenate. These data have dramatic ramifications for the delivery of DNA and RNA in vivo and to the development of inorganic metamaterials or composite NP for anticancer applications.

\section{Results and Discussion}

\subsection{DNA Stability in the Presence of $\mathrm{MgO} N \mathrm{NP}$}

The effect of the MgO NP on DNase digestion of plasmid DNA was examined. In this experiment, DNase was incubated at $4,85,65,45$, or $21{ }^{\circ} \mathrm{C}$ (rt: room temperature), then combined with $\mathrm{MgO}$, stained with ethidium bromide (ETBr) and analyzed by agarose gel electrophoresis. The results are shown in Figure 1.

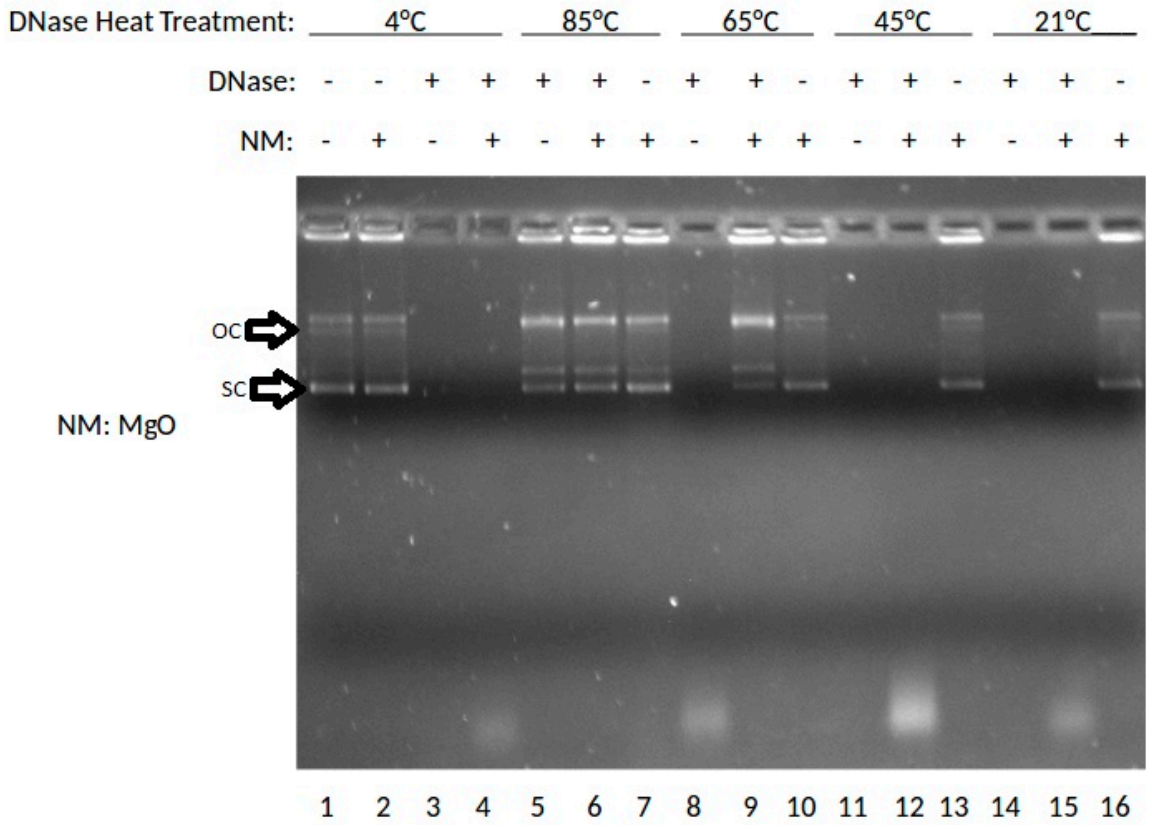

Figure 1. Effects of $\mathrm{MgO}$ on DNase activity at various temperatures shown by gel electrophoresis.

As shown in Figure 1, lane 1 shows the results for DNA without DNase or nanoparticle treatment where the super-coiled (SC) DNA migrates furthest in the gel and a stable open circle (OC) form runs midway down the gel followed by higher order species retained in the well. Lanes 2, 7, 10, 13, and 16 show DNA treated with MgO. Lanes 3, 5, 8, 11, and 14 show results for DNA treated with DNase. Lanes 4, 6, 9, 12, and 15 show results for DNA treated with DNase and $\mathrm{MgO}$. At $85^{\circ} \mathrm{C}$, 
the OC band becomes more prevalent and the linear band (not labeled) appears running between $\mathrm{OC}$ and SC. At $65^{\circ} \mathrm{C}$, the presence of $\mathrm{MgO}$ clearly protects against degradation with SC, OC and Lin bands present in the lane with nanomaterial (NM) present but no stained bands in the absence of NP. At 45 or $21^{\circ} \mathrm{C}$, intact DNA is only present when incubated with MgO NP. These data indicated a temperature-dependence of DNA stability to DNase degradation provided by MgO NP. The DNA stabilizing effect was buffer-dependent, especially at high non-physiological concentrations (100 or $400 \mathrm{mM}$ ) of either $\mathrm{MgCl}_{2}$ or $\mathrm{ZnCl}_{2}$ (data not shown).

\subsection{DNA Stability in the Presence of $\mathrm{ZnO} N \mathrm{~N}$}

The effect of the ZnO NP on DNase digestion of plasmid DNA was examined next. In this experiment, DNase was incubated at $4,85,65,45$, or $21^{\circ} \mathrm{C}(\mathrm{rt})$, then combined with $\mathrm{ZnO}$, stained with ETBr and analyzed by agarose gel electrophoresis similarly. The results are shown in Figure 2.

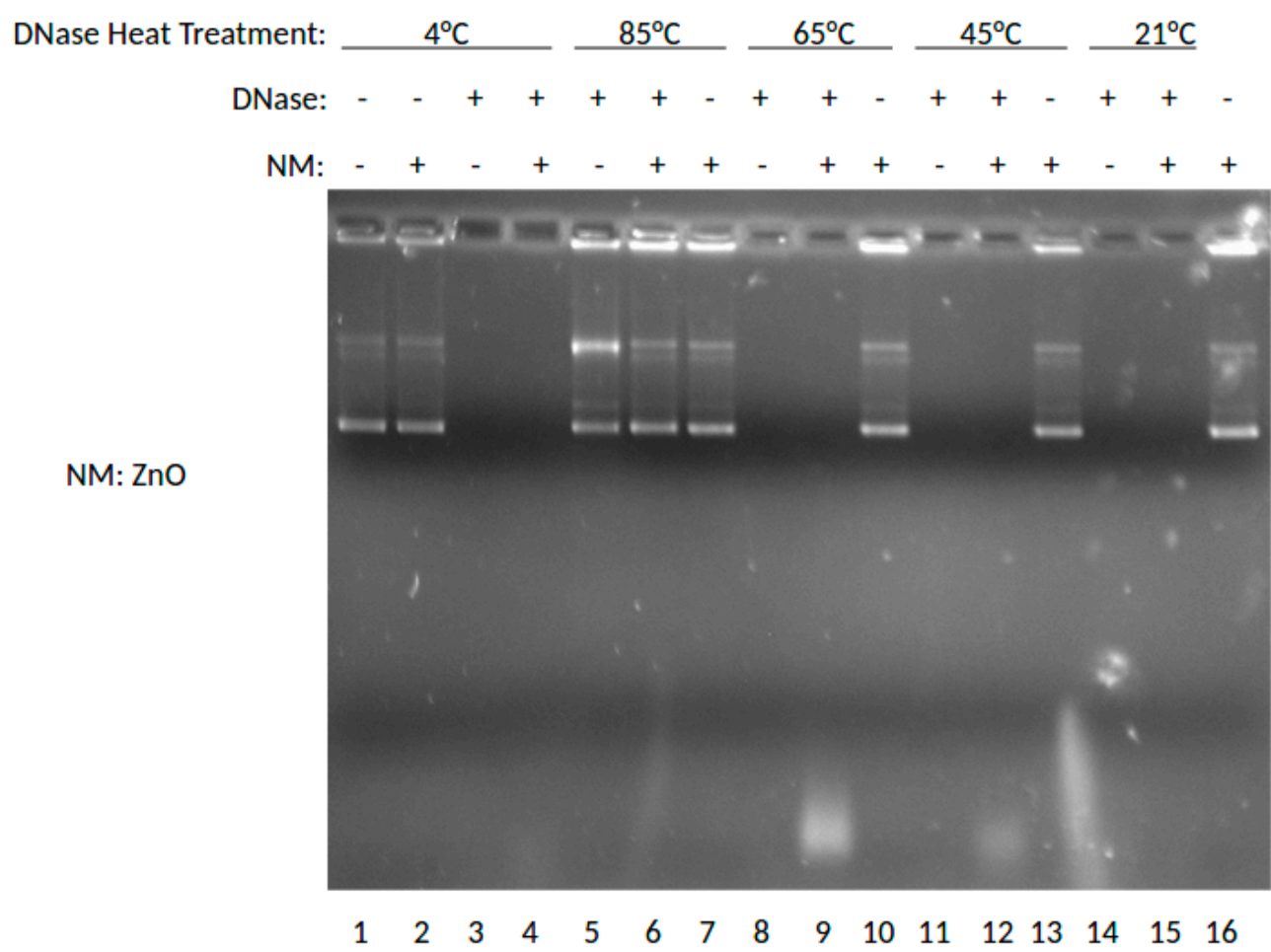

Figure 2. Effects of $\mathrm{ZnO}$ on DNase activity at various temperatures shown by gel electrophoresis.

As shown in Figure 2, this gel shows the effects of $\mathrm{ZnO}$ on degradation of DNA when treated with DNase previously incubated at varying temperatures. In this experiment, DNase was incubated at 4, $85,65,45$, and $21^{\circ} \mathrm{C}$ (room temperature), then combined with ZnO. Lane 1 shows the results for DNA without DNase or nanoparticle treatment at $4{ }^{\circ} \mathrm{C}$. Lanes $2,7,10,13$, and 16 show DNA treated with $\mathrm{ZnO}$. Lanes 3, 5, 8, 11, and 14 show results for DNA treated with DNase. Lanes 4, 6, 9, 12, and 15 show results for DNA treated with DNase and ZnO. By marked contrast, the presence of ZnO NP was not protective of DNA in this experiment, unlike $\mathrm{MgO}$ shown above. Thus, at neither temperature were intact DNA bands shown for DNase incubated with ZnO NP in the presence of DNA. DNA and RNA are known to interact with $\mathrm{ZnO} \mathrm{NP}[9,10]$ and it is interesting to note that in comparison to $\mathrm{MgO} \mathrm{NP}$ shown in Figure 1, the ZnO NP ratio of SC to OC appears to be slightly greater. Interestingly, ZnO NP was much more buffer-dependent than $\mathrm{MgO}$ and could be induced to provide DNase protection at higher buffer concentrations (data not shown). Taken together, these data would suggest that ZnO NP is able to interact with both DNA and protein consistent with previous observations [9-12], but that the $\mathrm{MgO}$ effect may be more driven by nucleic acid interaction. 


\subsection{RNA Stability in the Presence of Serum Provided by ZnO but Not MgO NP}

Poly inosinic:poly cytidilic acid (poly I:C) is a well-characterized anticancer RNA [5-7]. Our group has recently shown that intratumoral co-administration of poly I:C with ZnO NP has potent antitumor activity in a mouse model of experimental melanoma, inducing an antimetastatic biochemical and immunological profile [8]. For pharmacological activity, maintaining RNA stability in biological fluids and the tumor micro-environment is critical. Thus, the effect of $\mathrm{MgO}$ and $\mathrm{ZnO}$ NP on poly I:C digestion after exposure to fetal bovine serum (FBS) $[12,13]$ was examined next. The results are shown in Figure 3.

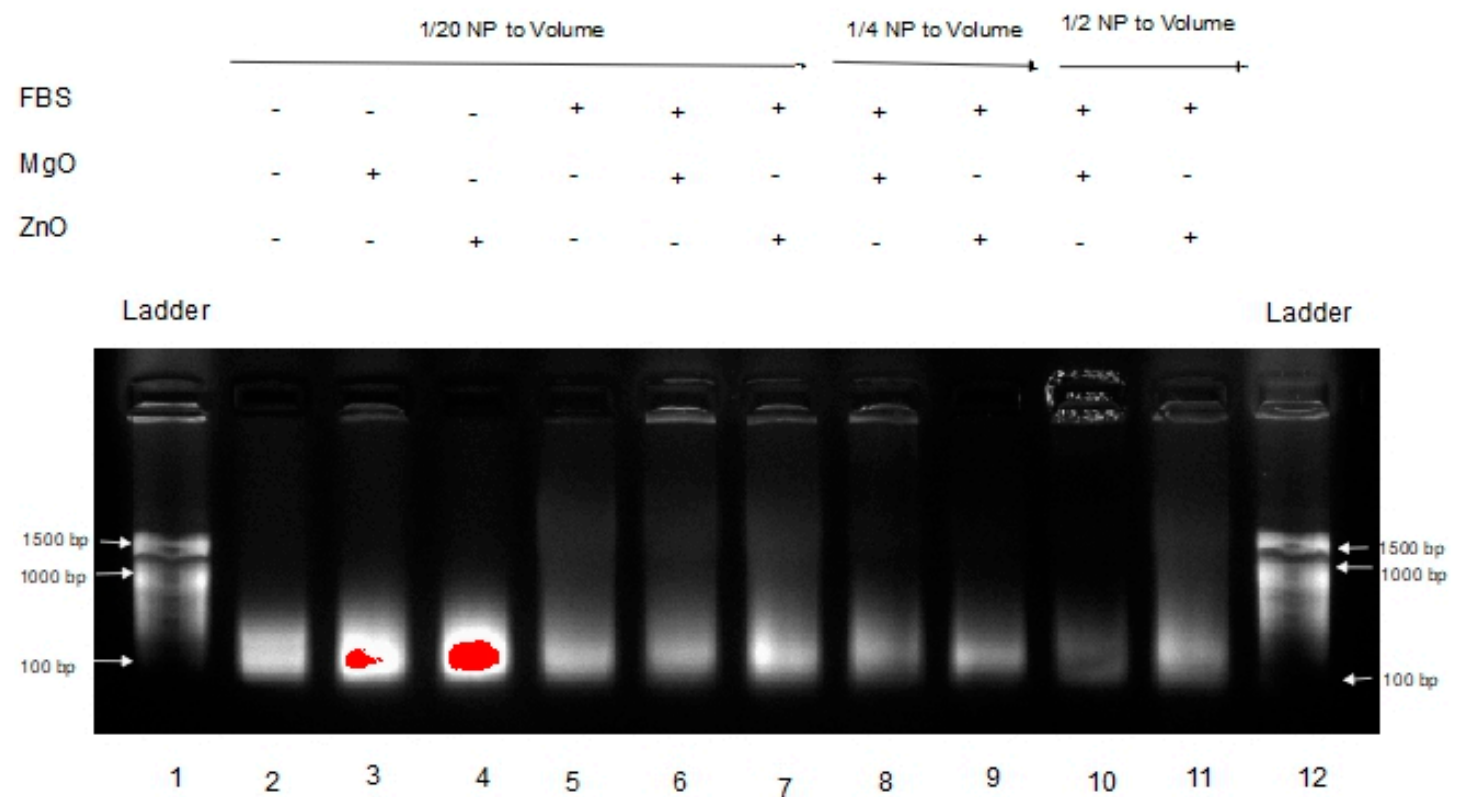

Figure 3. Effects of $\mathrm{MgO}$ and $\mathrm{ZnO}$ at various concentrations in Fetal Bovine Serum (FBS).

This gel shows the effects of $\mathrm{MgO}$ and $\mathrm{ZnO}$ in FBS, an environment known to have RNase activity [6,7]. Lanes 1 and 12 are DNA ladders for comparison. Lanes 2 through 4 are Poly I:C alone, with $\mathrm{MgO}$, and $\mathrm{ZnO}$, respectively, in water. Lanes 5 through 7 are Poly I:C with $\mathrm{MgO}$, and $\mathrm{ZnO}$, respectively, in FBS. Lanes 8 and 9 are Poly I:C with $\mathrm{MgO}$ and $\mathrm{ZnO}$, respectively, at a higher concentration (1/4 of volume sample) in FBS. Lanes 10 and 11 are Poly I:C with $\mathrm{MgO}$ and $\mathrm{ZnO}$, respectively, at a higher ratio of FBS (1/2 of volume sample). At each ratio, it is clear that the intensity of the poly I:C RNA band is greatest in the presence of $\mathrm{ZnO}$ than $\mathrm{MgO}$ NP. Using a separate sample of RNA from Torula yeast, $\mathrm{MgO}$ NP accelerated the rate of fluorescence band intensity loss relative to $\mathrm{ZnO}$ NP similarly (data not shown). These data suggested that $\mathrm{ZnO}$, but not $\mathrm{MgO} \mathrm{NP}$, protects RNA from hydrolysis.

\subsection{RNA Stability in the Presence of Tumor Homogenate Provided by $\mathrm{ZnO}$ but Not MgO NP}

Previously, we have shown that complexation to nanoparticle can protect RNA from degradation in tissue homogenate [13]. For an unmodified RNA such as long non-coding RNA, mRNA, RNA vaccines, etc., to exert robust function within the tumor environment, RNA stability is critical. Thus, poly I:C RNA stability in melanoma tumor homogenate for $\mathrm{ZnO}$ was compared to $\mathrm{MgO} \mathrm{NP}$. The results are shown in Figure 4. 


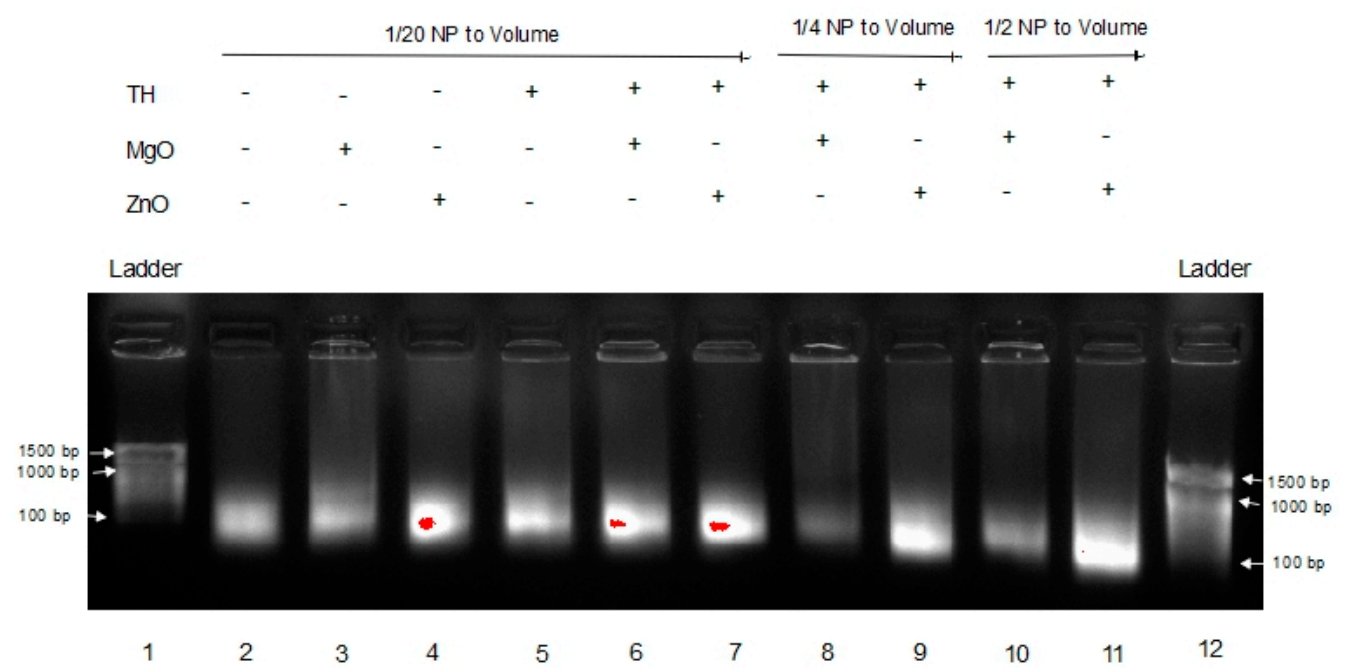

Figure 4. Effects of $\mathrm{MgO}$ and $\mathrm{ZnO}$ at various concentrations in Tumor Homogenate.

This gel shows the effects of $\mathrm{MgO}$ and $\mathrm{ZnO}$ in tumor homogenate, an environment known to have RNase activity. Lanes 1 and 12 are DNA ladders for comparison. Lanes 2 through 4 are Poly I:C alone, with $\mathrm{MgO}$, and $\mathrm{ZnO}$, respectively, in water. Lanes 5 through 7 are Poly I:C alone, with $\mathrm{MgO}$, and $\mathrm{ZnO}$, respectively, in tumor homogenate. Lanes 8 and 9 are Poly I:C with $\mathrm{MgO}$ and $\mathrm{ZnO}$, respectively, at a higher concentration (1/4 of volume sample) in tumor homogenate. Lanes 10 and 11 are Poly I:C with $\mathrm{MgO}$ and $\mathrm{ZnO}$, respectively, at a higher ratio (1/2 of volume sample) of tumor homogenate. The poly I:C band intensity was again greatest in the presence of $\mathrm{ZnO}$ in comparison to $\mathrm{MgO}$ NP. These data indicate that $\mathrm{ZnO}$, but not $\mathrm{MgO}$ NP, protects poly I:C RNA from degradation in the tumor homogenate.

\subsection{RNA Compatibility of NP}

Metal oxide NP generate reactive oxygen species (ROS) such as hydroxide radical and superoxides and $\mathrm{ZnO} \mathrm{NP}$ are known to form cationic hydrate species in aqueous buffer [12]. Prolonged exposure to these may therefore, in addition to hydrolysis, increase the rate of RNA degradation and certain silica or nitride NP are also known to split water or to effect RNA stability $[13,14]$. In this case, a pure macromolecular RNA from Torula yeast obtainable in bulk was used and exposed to NP in water and the RNA compatibility was assessed similarly by removing aliquots and analyzing them by RNA gel electrophoresis where the relative fluorescence intensity of the intact RNA band was plotted over time, as shown in Figure 5.

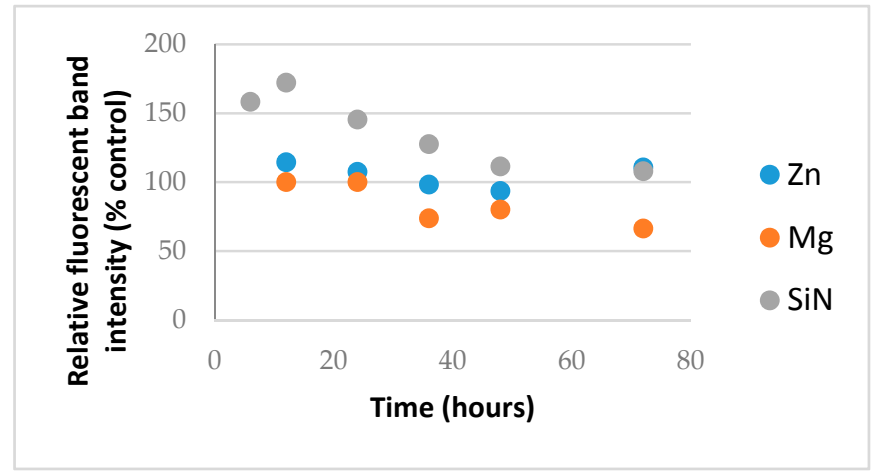

Figure 5. RNA compatibility of $\mathrm{ZnO}$ (blue) and $\mathrm{MgO}$ (orange) relative to silica nitride $\left(\mathrm{SiN}_{4}\right)$ control (grey). 
As shown in Figure 5, the control NP led to an initial increase in RNA stain intensity likely reflecting some denaturation of the RNA as the NP binds, allowing access to more dye molecules and then a gradual decline in the RNA band intensity as the RNA degrades. In the presence of $\mathrm{MgO}$, there was no initial increase but instead a loss of RNA from the supernatant likely caused by the aggregation of RNA and its loss from the supernatant consistent with bands in the well-being higher-order species observed in the previous gels. This is in contrast to chemical degradation inferred from the control. Importantly, in the presence of $\mathrm{ZnO} \mathrm{NP}$, however, no physicochemical alteration in the RNA, at least by relative fluorescence intensity of the full-length RNA difference from control RNA receiving no NP, was detected during $72 \mathrm{~h}$ of exposure.

\section{Materials and Methods}

\subsection{Materials}

Nanoscale $\mathrm{ZnO}(<100 \mathrm{~nm})$ and $\mathrm{MgO}(<50 \mathrm{~nm})$, poly inosinic:poly cytidilic acid (poly I:C), torula yeast RNA and DNase were obtained from Sigma-Aldrich (St. Louis, MO, USA). The nanoparticle size and zeta potential were confirmed on a Malvern Zetananosizer (Westborough, MA, USA) as per our previous reports $[4,8,9]$. The NP were washed with double-distilled water $\left(\mathrm{ddH}_{2} \mathrm{O}\right)$ and precipitated from alcohol and air-dried to a powder within a biological safety cabinet prior to use. Stock samples were generally prepared at $1 \mathrm{mg} / \mathrm{mL}$ in sterile $\mathrm{ddH}_{2} \mathrm{O}$ except for tumor homogenate which was prepared from sterile PBS (phosphate-buffered saline) and FBS was obtained from Hyclone (South Logan, UT, USA), thawed and used directly.

\subsection{DNA Degradation with Heat-Killed DNase}

Gel electrophoresis was conducted to test the DNA degradation with heat-killed DNase. In this experiment, $20-\mu \mathrm{L}$ samples were created consisting of $1 \mu \mathrm{L}$ of $1.0 \mu \mathrm{g} / \mu \mathrm{L}$ DNA (puc118 plasmid; Clontech Cat.\# 3318, Takara Bio USA Inc., Mountain View, CA, USA) and varying concentrations of DNase to make up the volume. The DNase was used at a concentration of 1:40 and the NP were at a concentration of $1 \mathrm{mg} / \mathrm{mL}$. One sample of each concentration of DNase was heat denatured by incubation for $30 \mathrm{~min}$ at $75^{\circ} \mathrm{C}$. Then, all samples were incubated at $25^{\circ} \mathrm{C}$ for $30 \mathrm{~min}$. A volume of $2 \mu \mathrm{L}$ loading dye was added to each sample (after NanoDrop of both). Samples were then assayed in $1 \%$ agarose gel (100 $\mathrm{mA}$ for $45 \mathrm{~min}$ ), followed by staining using ethidium bromide (EtBr).

\subsection{RNA Degradation}

In both gels, Poly I:C was used at a stock concentration of $355 \mu \mathrm{g} / \mathrm{mL}$. Each sample had $1 \mu \mathrm{L}$ of this solution for a 1:19 Poly I:C to total volume ratio. Both the $\mathrm{MgO}$ and $\mathrm{ZnO}$ came from stock solutions of $1 \mathrm{mg} / \mathrm{mL}$. Depending on the sample, each sample either had $1 \mu \mathrm{L}$ (1:19), $5 \mu \mathrm{L}$ (1:3), or $10 \mu \mathrm{L}$ (1:1) of the $\mathrm{MgO}$ or $\mathrm{ZnO} \mathrm{NP}$ stock suspension, sonicated and vortexed prior to its addition to DNase, or to RNA or DNA in solution. The FBS and tumor homogenate were $3 \mu \mathrm{L}$ in all the samples in which they were used (3:17). Poly I:C, MONP (metal oxide nanoparticle), and FBS or tumor homogenate were combined with ultrapure water (enough to create $18 \mu \mathrm{L}$ of solution so that when the $40 \% \mathrm{w} / \mathrm{v}$ sucrose and Safestain were added, there would be $20 \mu \mathrm{L}$ per sample/well) in microcentrifuge tubes and incubated at $37^{\circ} \mathrm{C}$ for $1 \mathrm{~h}$. After $1 \mathrm{~h}$, they were combined with $1 \mu \mathrm{L}$ of sucrose and $1 \mu \mathrm{L}$ of Bullseye DNA Safestain (C138) (Midwest Scientific, Valley Park, MO, USA), and then electrophoresed on an 1\% agarose/TAE (Tris base, acetic acid, and EDTA) gel at $100 \mathrm{~V}$ for $20 \mathrm{~min}$. They were then imaged using a Bio-Rad Molecular Imager GelDoc ${ }^{\mathrm{TM}}$ XR+ Imaging System (Hercules, CA, USA).

\subsection{RNA Compatibility}

Torula yeast (Sigma-Aldrich, St. Louis, MO, USA) was dissolved in RNase-free double-distilled deionized water at $1 \mathrm{mg} / \mathrm{mL}$. To an equal volume of RNA was added a $1 \mathrm{mg} / \mathrm{mL}$ suspension also in RNase-free double-distilled water. The two were vortex mixed briefly for 10 to $15 \mathrm{~s}$ and exposed to 
physiological temperature and at 6, 12, 24, 36, 48 and $72 \mathrm{~h}$, samples were removed and electrophoresed on $1 \%$ agarose/TAE, fluorescently stained with ethidium bromide and the band intensities determined on a Kodak Gel Logic 200 Imaging System (Rochester, NY, USA).

\section{Conclusions}

The results suggest that RNA is best protected by ZnO NP, and DNA by MgO NP. Recently, our group elucidated the molecular mechanism by which RNA interacts to ZnO NP which involved interaction both to the phosphodiester and base [9]. In the absence of direct protein interaction which we know is possible for ZnO NP [15], this would suggest that its RNA interaction either restricts RNase access or sterically blocks the enzyme from being able to cleave the phosphodiester bond. The thermal protection provided by $\mathrm{MgO}$ to DNA from DNase digestion, however, suggests a different mechanism is operative, whereby its protein interaction is able to preserve protein structure and hence function under conditions which would normally denature it. Results from Figure 1 suggest that $\mathrm{MgO}$ can decrease DNase degradation of DNA under certain parameters. From Figure 1, it can be determined that $\mathrm{MgO}$ decreases DNase activity when the DNase is incubated at $65{ }^{\circ} \mathrm{C}$-a temperature that is known to be denaturing to the DNase enzyme, but at which it can still function. The results from Figure 2 regarding $\mathrm{ZnO}$ treatment did not show a significant decrease in DNase activity under any temperature tested. This can be seen because in Lanes 5, 6, 7, and 9 of Figure 1, three distinct bands can be seen. These bands represent, from the top, supercoiled DNA that is still intact, open circle DNA where one strand has been damaged, and linear DNA where both strands have been damaged. In Figure 2, only Lane 5 shows the same three bands, indicating that the $\mathrm{ZnO}$ added in the other lanes did not protect the DNA from degradation.

In Figure 3, a dimmer signature can be seen in the $\mathrm{MgO}$ samples in FBS versus the $\mathrm{ZnO}$ samples in FBS, indicating that the RNA in those samples either experienced more degradation or were tied up in higher-order complexes or species, resulting in less free RNA able to migrate through the gel. This is seen even more severely in Figure 4 when the samples are in tumor homogenate rather than FBS. Even at higher concentrations of $\mathrm{MgO}$, it is unable to protect the RNA from degradation by its RNase-active environment. With fewer and less concentrated proteins expected from tumor homogenate than serum-containing media, this suggests that this affect is more nuclease-protective than an aggregation phenomenon triggered by the protein corona to $\mathrm{MgO}$ or lack thereof from $\mathrm{ZnO}$ NP, although more research would be required to conclusively demonstrate this.

Acknowledgments: This work was supported by NIH/NCI R15 grant "Anticancer RNA Nanoconjugates" (7R15CA139390-03) to R.K.D.

Author Contributions: Jayden McCall: Performed the RNA degradation gels in Figures 3 and 4 and wrote much of the manuscript. Joshua J. Smith: Mentored Marquardt, Knight, and Barber and edited the manuscript. Kelsey N. Marquardt: Performed the DNA degradation gels in Figures 1 and 2 with Knight. Katelin R. Knight: Performed the DNA degradation gels in Figures 1 and 2 with Marquardt. Hunter Bane: Performed the RNA stability with $\mathrm{ZnO}, \mathrm{MgO}$, and $\mathrm{SiN}$ in Figure 5. Alice Barber: Did preliminary research to get the DNA degradation experiments started. Robert K. DeLong: Mentored McCall, Bane, and Barber and assisted McCall in compiling information for the manuscript and co-edited it.

Conflicts of Interest: The authors declare no conflict of interest.

\section{References}

1. Zhang, H.; Ji, Z.; Xia, T.; Meng, H.; Low-Kam, C.; Liu, R.; Pokhrel, S.; Lin, S.; Wang, X.; Liao, Y.P.; et al. Use of metal oxide nanoparticle band gap to develop a predictive paradigm for oxidative stress and acute pulmonary inflammation. ACS Nano 2012, 6, 4349-4368. [CrossRef] [PubMed]

2. Moon, S.H.; Choi, W.J.; Choi, S.W.; Kim, E.H.; Kim, J.; Lee, J.O.; Kim, S.H. Anti-cancer activity of ZnO chips by sustained zinc ion release. Toxicol. Rep. 2016, 3, 430-438. [CrossRef] [PubMed]

3. Roy, R.; Singh, S.K.; Chauhan, L.K.; Das, M.; Tripathi, A.; Dwivedi, P.D. Zinc oxide nanoparticles induce apoptosis by enhancement of autophagy via PI3K/Akt/mTOR inhibition. Toxicol. Lett. 2014, 227, $29-40$. [CrossRef] [PubMed] 
4. DeLong, R.K.; Mitchell, J.A.; Morris, R.T.; Comer, J.; Hurst, M.N.; Ghosh, K.; Wanekaya, A.; Mudge, M.; Schaeffer, A.; Washington, L.L.; et al. Enzyme and cancer cell selectivity of nanoparticles: Inhibition of 3-D metastatic phenotype and experimental melanoma by zinc oxide. J. Biomed. Nanotechnol. 2017, 13, 221-231. [CrossRef]

5. Cheng, Y.S.; Xu, F. Anticancer function of polyinosinic-polycytidylic acid. Cancer Biol. Ther. 2010, 10, 1219-1223. [CrossRef] [PubMed]

6. Cobaleda-Siles, M.; Henriksen-Lacey, M.; Ruiz de Angulo, A.; Bernecker, A.; Gómez Vallejo, V.; Szczupak, B.; Llop, J.; Pastor, G.; Plaza-Garcia, S.; Jauregui-Osoro, M.; et al. An iron oxide nanocarrier for dsRNA to target lymph nodes and strongly activate cells of the immune system. Small 2014, 10, 5054-5067. [CrossRef] [PubMed]

7. Forte, G.; Rega, A.; Morello, S.; Luciano, A.; Arra, C.; Pinto, A.; Sorrentino, R. Polyinosinic-polycytidylic acid limits tumor outgrowth in a mouse model of metastatic lung cancer. J. Immunol. 2012, 188, 5357-5364. [CrossRef] [PubMed]

8. $\quad$ Ramani, M.; Mudge, M.C.; Morris, R.T.; Zhang, Y.; Warcholek, S.A.; Hurst, M.N.; Riviere, J.E.; DeLong, R.K. Zinc Oxide Nanoparticle-Poly I:C RNA Complexes: Implication as Therapeutics against Experimental Melanoma. Mol. Pharm. 2017, 14, 614-625. [CrossRef] [PubMed]

9. Ramani, M.; Nguyen, T.D.T.; Aryal, S.; Ghosh, K.C.; DeLong, R.K. Elucidating the RNA Nano-Bio Interface: Mechanisms of Anticancer Poly I:C RNA and Zinc Oxide Nanoparticle Interaction. J. Phys. Chem. C 2017, 121, 15702-15710. [CrossRef]

10. He, Y.; Ingudam, S.; Reed, S.; Gehring, A.; Strobaugh, T.P., Jr.; Irwin, P. Study on the mechanism of antibacterial action of magnesium oxide nanoparticles against foodborne pathogens. J. Nanobiotechnol. 2016, 14, 54. [CrossRef] [PubMed]

11. Leung, Y.H.; Ng, A.M.; Xu, X.; Shen, Z.; Gethings, L.A.; Wong, M.T.; Chan, C.M.; Guo, M.Y.; Ng, Y.H.; Djurišić, A.B.; et al. Mechanisms of antibacterial activity of MgO: Non-ROS mediated toxicity of MgO nanoparticles towards Escherichia coli. Small 2014, 10, 1171-1183. [CrossRef] [PubMed]

12. Kang, H.; DeLong, R.; Fisher, M.H.; Juliano, R.L. Tat-conjugated PAMAM dendrimers as delivery agents for antisense and siRNA oligonucleotides. Pharm. Res. 2005, 22, 2099-2106. [CrossRef] [PubMed]

13. Reyes-Reveles, J.; Sedaghat-Herati, R.; Gilley, D.R.; Schaeffer, A.M.; Ghosh, K.C.; Greene, T.D.; Gann, H.E.; Dowler, W.A.; Kramer, S.; Dean, J.M.; et al. mPEG-PAMAM-G4 nucleic acid nanocomplexes: Enhanced stability, RNase protection, and activity of splice switching oligomer and poly I: C RNA. Biomacromolecules 2013, 14, 4108-4115. [CrossRef] [PubMed]

14. Cha, S.H.; Hong, J.; McGuffie, M.; Yeom, B.; Van Epps, J.S.; Kotov, N.A. Shape-Dependent Biomimetic Inhibition of Enzyme by Nanoparticles and Their Antibacterial Activity. ACS Nano 2015, 9, 9097-9105. [CrossRef] [PubMed]

15. Zheng, D.W.; Li, B.; Li, C.X.; Fan, J.X.; Lei, Q.; Li, C.; Xu, Z.; Zhang, X.Z. Carbon-Dot-Decorated Carbon Nitride Nanoparticles for Enhanced Photodynamic Therapy against Hypoxic Tumor via Water Splitting. ACS Nano 2016, 10, 8715-8722. [CrossRef] [PubMed]

(C) 2017 by the authors. Licensee MDPI, Basel, Switzerland. This article is an open access article distributed under the terms and conditions of the Creative Commons Attribution (CC BY) license (http://creativecommons.org/licenses/by/4.0/). 